\title{
繰返し変形による疲労と温度上昇の効果を取り入れた 高減衰積層ゴムの解析モデルの検討 \\ MODELING FOR ANALYSIS OF HIGH DAMPING RUBBER BEARINGS WITH EFFECTS OF FATIGUE AND TEMPERATURE INCREASE DUE TO REPEATED DEFORMATION
}

\author{
森 隆浩*, 加藤秀章**, 室田伸夫*** \\ Takahiro MORI, Hideaki KATO and Nobuo MUROTA
}

\begin{abstract}
In this study, we propose FEM analysis model and time history response analysis model for high damping rubber bearings. These models can be used for the condition of repeated deformation which is often caused by the long-period ground motion or wind response. In this condition, high damping rubber bearings experience stiffness degradation due to fatigue and temperature increase of inner rubber. First, by taking account of these two effects, we establish the constitutive law of high damping rubber material for FEM analysis model and check the reproductivity of test results. Next, we derive the hysteresis model from the constitutive law of high damping rubber material. A prediction equation of temperature increase for the hysteresis model is determined from thermal FEM analysis.
\end{abstract}

Keywords : High damping laminated rubber bearings, Long-period ground motion, Time history response analysis model, Finite element method, Fatigue, Temperature increase 高減衰積層ゴム, 長周期地震動, 時刻歴応答解析モデル, 有限要素法, 疲労, 温度上昇

\section{1. はじめに}

近年、防災に対する関心の高まりにより、特に高層建物を中心に 建築物の免震化が進んでいる。それに伴い、積層ゴムに代表される 免震装置において、大地震時の効果も実証されつつある。一方で、 東南海地震等の海溝型の巨大地震によって内陸部に発生が予測され る長周期地震動により、長周期化された免震建物が共振する可能性 が䯚念されている。このような条件下では、積層ゴムは長時間にわ たる繰返し大変形を受ける。特に高減衰積層ゴムや鉛挿入型積層ゴ ムなど、減衰性能を有する積層ゴムが多数回の繰返し変形を受ける と、発熱による内部ゴムや鉛の温度上昇によって、剛性や減衰性能 の低下を引き起こすことが知られている ${ }^{1)}$ 。また、特に高減衰ゴム 材料においては、Mullin's 効果 ${ }^{2)}$ に代表されるように、繰返し加力の

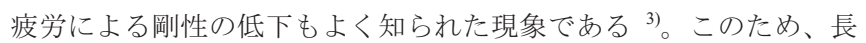
周期地震動による多数回の繰返し大変形を想定した免震装置の健全 性評価も数多く行われるようになった ${ }^{4)}$, 5), 6)。また、実験評価だけで なく、多数回の繰返し大変形挙動を予測する解析モデルに関する研 究もなされている。鈆挿入型積層ゴムにおいては、前進差分法を応 用した簡易な熱伝導解析によって鉛の温度上昇を計算し、鉛の降伏 応力低下の効果を取入れた解析手法が提案されている7)。高減衰積 層ゴムにおいても、同様に温度上昇による剛性低下の効果を考慮し
た解析モデルが提案されているが ${ }^{8)}$ 、サイズ効果も考慮した高減衰 積層ゴムの解析モデルは、これまでに提案されていない。高減衰積 層ゴムの内部ゴムの温度上昇は、サイズや形状に対する依存性が無 視できないと考えられ、サイズや形状依存性を考慮した解析モデル の構築は重要である。また、繰返し変形による温度上昇や疲労によ る剛性の低下は、長周期地震動下のみでなく、風荷重載荷によって も生じる。高減衰積層ゴムや鉛挿入型積層ゴムにおいて、動的な風 荷重の長時間加力試験を行い、温度上昇を伴うような荷重条件下で

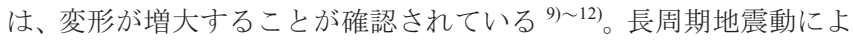
る積層ゴムの変形はせん断ひずみ $200 \%$ 程度の大変形が 10 数分間程 度継続することが想定されるが、風荷重による変形は数十\%の小さ い振幅で数時間継続すると考えられる。即ち、長周期地震動と風荷 重では、繰返しにおける変形スケールと時間スケールが若干異なる。 本研究における解析モデルは、風荷重にも適用できることを念頭に おき、変形スケールや時間スケールの違いにも注意を払いつつモデ ル化を行う。

以上のような背景の下、本研究では、高減衰積層ゴムの繰返し変 形下における挙動を解析によって予測することを目的に、有限要素 法(FEM)による解析モデルと、時刻歴応答解析モデルを提案する。 両解析モデルともに、上述した「疲労」と「温度上昇」の 2 種類の
* (株ブリヂストンインフラ資材開発部 博士(理学)

** (株)ブリヂストンインフラ資材開発部 修士(理学)

*** (株)ブリヂストンインフラ資材開発部 ユニットリーダー・Ph. D.
Infrastructure Products Development Dept., Bridgestone Co., Dr. Sci.

Infrastructure Products Development Dept., Bridgestone Co., M. Sci.

Mgr., Infrastructure Products Development Dept., Bridgestone Co., Ph. D. 
影響を考慮し、多数回の繰返し変形による剛性低下の効果を取入れ ている。

高減衰積層ゴムの FEM 解析モデルにおいては、高減衰ゴム材料 の構成則が最も重要となる。本論文では、過去、筆者らによって提 案された変形履歴積分型の弾塑性構成則 $\left.{ }^{13)},{ }^{14}\right)$ に対し、「疲労」と「温 度上昇」による剛性低下の効果を付加し、高精度化した高減衰ゴム の材料構成則を新たに提案する。本研究における FEM 解析モデル は、変形に伴う発熱による温度上昇の効果を取入れているため、熱構造の連成解析となる。

一方、時刻歴応答解析モデルの導出には、加藤らが高減衰ゴムの 材料構成則を 1 自由度系の単純せん断変形モデルに縮退することで、 導き出した手法 ${ }^{15)}$ を用いた。本研究では、この手法を「単純せん断 モデルへの縮退化」と呼ぶこととする。上述の通り、時刻歴応答解 析モデルにおいても、温度上昇の効果を考慮する必要があり、提案 するモデルは温度を内部パラメータとして持っている。しかしなが ら、積層ゴムの温度上昇は積層ゴムのサイズや構造に大きく依存す るため、FEM 解析モデルと異なり、温度上昇の予測が難しい。そこ で、温度上昇における積層ゴムのサイズ・構造依存性を調べ、その 結果から温度上昇を予測する予測式が必要になる。この予測式は、 実大試験体を含む実験により構築することが望ましい。しかしなが ら、実験により温度上昇のサイズ依存性を調べるには、非常に多く の実験が必要となる。また、温度上昇のサイズ依存性の評価には動 的に加力することが重要と考えられるが、実スケール試験体の動的 加力が難しいなどの問題がある。そこで本研究では、熱伝導 FEM 解 析によって、積層ゴム内部の温度上昇を予測する。まずサイズや構 造を様々に変化させた場合の熱伝導 FEM 解析によって積層ゴムの 内部ゴムの温度上昇を計算し、温度上昇のサイズ・構造依存性を調 べる。次に、積層ゴムのサイズや構造を変数とした内部ゴムの温度 上昇予測式を構築する。この温度上昇予測式と、温度に依存する時 刻歴応答解析モデルを連立して解くことで、温度上昇に伴う剛性低 下を表現できる時刻歴応答解析が可能となる。

本論文の構成は以下の通りである。2 章では、FEM 解析において 最も重要となる内部ゴムの材料構成則を提案する。さらに、内部ゴ ムの材料構成則の単純モデルへの縮退化によって、時刻歴応答解析 モデルを提案する。 3 章では、2 章で提案した解析モデルの高減衰 ゴムの材料パラメータの同定手順を示す。 4 章では、FEM 解析モデ ルの詳細を説明する。また、熱一構造の連成 FEM 解析を実施し、 実験結果の再現性を確認する。5 章では、時刻歷応答解析一の適用 を想定し、様々なサイズや構造の積層ゴムの熱伝導 FEM 解析を実 施することで、温度上昇予測式を構築する。最後に 6 章で、本研究 の結論とまとめを述べる。

\section{2. 解析モデル}

\section{1 FEM を想定した内部ゴムの弾塑性構成則}

本研究で提案する有限要素解析を想定した高減衰ゴムの材料構成 則は、筆者らによって提案された以下に示す変形履歴積分型の弾塑

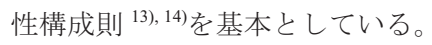

$$
\boldsymbol{S}=2 \frac{\partial W_{\mathrm{dev}}}{\partial \boldsymbol{C}}+2 \frac{\partial W_{\mathrm{vol}}}{\partial \boldsymbol{C}}+2 \sum_{i=1}^{n} g_{i} \int_{0}^{L} \frac{\mathrm{d}}{\mathrm{d} L^{\prime}}\left(\frac{\partial \bar{W}_{0}}{\partial \boldsymbol{C}}\right) e^{-\left(L-L^{\prime}\right) h_{i}} \mathrm{~d} L^{\prime}
$$

$$
L=\int_{0}^{t} \sqrt{\frac{2}{3} \boldsymbol{D}^{\prime}: \boldsymbol{D}^{\prime}} \mathrm{d} t
$$

$$
\begin{aligned}
& W_{\mathrm{dev}}=C_{10}\left(I_{1}-3\right)+C_{20}\left(I_{1}-3\right)^{2} \\
& W_{\mathrm{vol}}=\frac{1}{2} \kappa\left(\sqrt{I_{3}}-1\right)^{2} \\
& \bar{W}_{0}=\bar{I}_{1}-3
\end{aligned}
$$

ここで、 $S$ は第 2 Piola-Kirchhoff 応カテンソル、C は右 Cauthy-Green テンソル、 $I_{1} 、 I_{3} 、 \bar{I}_{1}$ はそれぞれ右 Cauthy-Green テンソルの第 1 不変 量、第 3 不変量、第 1 低減不变量 $\left(\bar{I}_{1}=I_{1} / I_{3}\right)$ である。 $W_{\mathrm{dev}} 、 W_{\mathrm{vol}} 、 \bar{W}_{0}$ は 超弾性のひずみエネルギー密度関数を表し、特に $W_{\mathrm{dev}}$ は等容変形に、 $W_{\mathrm{vol}}$ は体積変形に関するひずみエネルギー密度関数である。 $C_{10} 、 C_{20}$ 、 $\kappa 、 l_{i} 、 g_{i}$ は材料パラメータを表す。式(2.1)〜(2.5)のままでは、繰返 し変形による疲労や温度上昇によるゴムの剛性低下を表現できない。 そこで、式(2.1)に対して温度と疲労の効果を考慮し、式(2.6)で表現 される構成則に改良した。

$$
\boldsymbol{S}=2 \Xi_{e} \frac{\partial W_{\mathrm{dev}}}{\partial \boldsymbol{C}}+2 \frac{\partial W_{\mathrm{vol}}}{\partial \boldsymbol{C}}+2 g \Xi_{p} F(T) \int_{0}^{L} \frac{\mathrm{d}}{\mathrm{d} L^{\prime}}\left(\frac{\partial \bar{W}_{0}}{\partial \boldsymbol{C}}\right) e^{-\left(L-L^{\prime}\right) / l} \mathrm{~d} L^{\prime}
$$

式(2.6)からわかるように、式(2.1)において $n=1$ としている。文献 13) に示したように、材料パラメータ $l_{i} 、 g_{i}$ が高減衰ゴム材料の持つク リープ特性を決める。クリープ特性も高精度に表現したい場合には、 $n$ を 2 以上にする必要があるが、本研究ではクリープ特性には着目 せず、積層ゴムのせん断応力一せん断ひずみ特性の再現に着目して いる。そのため、 $n=2$ としても問題はないが、単純化のために本研 究では $n=1$ とした。 $F(T)$ は温度 $T\left({ }^{\circ} \mathrm{C}\right)$ の関数であり、

$$
F(T)=\theta_{T}+\left(1-\theta_{T}\right) \exp \left(-\frac{(T-20)}{\beta_{T}}\right)
$$

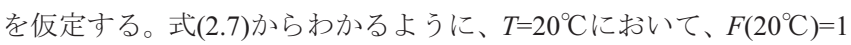
となる。また、 $\Xi_{e} 、 \Xi_{p}$ は Miehe らによって提案されたダメージ関数 ${ }^{16)}$ のうち、連続タイプのものを採用した。 $\Xi_{e} 、 \Xi_{p}$ は、過去に受けた 変形履歷に依存し、

$$
\begin{aligned}
& \Xi_{e}=\theta_{e}+\left(1-\theta_{e}\right) \exp \left(-\frac{\int\left|\mathrm{d} W_{\mathrm{dev}}\right|}{\beta_{e}}\right) \\
& \Xi_{p}=\theta_{p}+\left(1-\theta_{p}\right) \exp \left(-\frac{\int\left|\mathrm{d} W_{\mathrm{dev}}\right|}{\beta_{p}}\right)
\end{aligned}
$$

で定義する。 $\theta_{T} 、 \theta_{e} 、 \theta_{p} 、 \beta_{T} 、 \beta_{e} 、 \beta_{p}$ は材料パラメータである。式(2.6) 〜(2.9)からわかるように、内部ゴムのエネルギー吸収量は温度上昇 及びダメージ関数 $\Xi_{p}$ に依存して低下し、弾性率はダメージ関数 $\Xi_{e}$ に依存して低下寸ると仮定した。式(2.6)からわかるように、体積変 形成分を表す $W_{\mathrm{vol}}$ に対しては、剛性低下の影響を考慮していない。 ゴムの体積弾性率も温度依存性等があると考えられるが、ゴムは非 圧縮性の材料であり、積層ゴムの圧縮せん断変形に与える $W_{\mathrm{vol}}$ の影 響は $W_{\mathrm{dev}}$ に比べるとかなり小さい。そのため、本研究では $W_{\mathrm{vol}}$ に対 する温度依存性等の影響は無視した。4 章で、式(2.2)〜(2.9)を用い た熱一構造の連成 FEM 解析を行う。

\section{2 時刻歴応答解析モデル}

積層ゴムは、薄いゴムと鋼板の積層構造であり、ゴムは単純せん 
断に近い変形を示す。過去、筆者らによって、式(2.1)〜 (2.5)の材料 構成則を、1 自由度系の単純せん断変形に縮退することにより、時 刻歴応答解析モデルの提案を行った。本研究においても、同様の手 法で時刻歴応答解析モデルを導く。2.1 節にて提案した材料構成 則(2.2)〜(2.9)を単純せん断モデルへ縮退化すると、以下の解析モデ ル(せん断応力 $\tau$ 一せん断ひずみ $\gamma$ 関係)が導かれる。

$$
\begin{aligned}
& \tau(\gamma)=\Xi_{e}\left(a \gamma+b \gamma^{3}\right)+g^{*} \Xi_{p} F(T) \int_{0}^{\gamma} e^{-\left(\gamma-\gamma^{\prime}\right) / l^{*}}\left(\gamma^{\prime 2}-\frac{2}{3} \gamma \gamma^{\prime}+1\right) \mathrm{d} \gamma^{\prime} \\
& \Gamma=\Gamma(\gamma)=\int_{0}^{\gamma}|\mathrm{d} \gamma| \\
& F(T)=\theta_{T}+\left(1-\theta_{T}\right) \exp \left(-\frac{(T-20)}{\beta_{T}}\right) \\
& \Xi_{e}=\theta_{e}+\left(1-\theta_{e}\right) \exp \left(-\frac{\int\left|\left(a \gamma+b \gamma^{3}\right) \mathrm{d} \gamma\right|}{\beta_{e}}\right) \\
& \Xi_{p}=\theta_{p}+\left(1-\theta_{p}\right) \exp \left(-\frac{\int\left|\left(a \gamma+b \gamma^{3}\right) \mathrm{d} \gamma\right|}{\beta_{p}}\right)
\end{aligned}
$$

$a 、 b 、 l^{*} 、 g^{*}$ は物性パラメータであり、弾塑性構成則(2.2) (2.9)にお ける物性パラメータ $C_{10} 、 C_{20} 、 l 、 g$ との間に、 $a=2 C_{10} 、 b=4 C_{20} 、 l^{*}=$ $\sqrt{3} l 、 g^{*}=2 g$ の関係が成り立つ。このように、材料構成則から時刻歴 応答解析モデルを導くことの利点として、FEM 解析モデルと時刻歴 応答解析モデルで同一の材料パラメータを用いることができること が挙げられる。

温度については、以下に示す温度上昇予測式を仮定する。

$$
\Delta T=\alpha\left[T_{\infty}(q)-T\right] q \Delta t
$$

$T$ は内部ゴムの体積平均温度であり、初期状態 $t=0$ では外気温度 $T_{0}$ と等しく、 $T=T_{0}$ である。 $\Delta T$ は微小時間 $\Delta t$ での内部ゴムの体積平均 温度の変化量、 $q$ は $\Delta t$ における積層ゴムの変形による内部ゴムの単 位体積・単位時間当たりの発熱量である。 $\alpha$ は積層ゴムの形状によ って決まる定数であり、 $T_{\infty}$ は積層ゴムがその瞬間の発熱量 $q$ で発熱 し続けた場合に、内部発熱と積層ゴム表面からの発熱量がつりあっ た状態 $(t=\infty)$ での収束温度である。 $T_{\infty}$ は、積層ゴムの形状に依存し、 発熱量 $q$ に比例する。式(2.15)は物理的には、単位時間当たりの温度 上昇 $\Delta T$ が、発熱量 $q$ における収束温度 $T_{\infty}$ と現在の温度 $T$ の差 $T_{\infty}-T$ と、発熱量 $q$ に比例することを意味する。1 章で述べたとおり、 $\alpha$ と $T_{\infty}$ の形状依存性については、 5 章にて FEM 解析により決定し、 式(2.15)の妥当性についても議論する。

\section{3. 内部ゴムの材料パラメータの同定}

高減衰ゴムの材料パラメータの同定は、時刻歷応答解析モデル の解析結果と、せん断試験片による加力実験や積層ゴムの加力実験 結果が合うように、以下に述べる(1)〜 (3)の手順で決定した。同定し た内部ゴムの物性パラメータ值は表 1 に示す。

(1) $C_{10} 、 C_{20} 、 \kappa 、 g 、 l$ の決定 : $C_{10} 、 C_{20} 、 \kappa 、 g 、 l$ については、文献 13) と同一の方法でパラメータを決定した。

(2) $\beta_{T} 、 \theta_{T}$ の決定 : 時刻歴応答解析モデル $(2.10) \sim(2.14)$ と図 1 に示す ゴムのせん断試験片による温度依存性評価結果が一致するよう に決定した。ゴムの形状は一辺が $25 \mathrm{~mm}$ の正方形であり、ゴム厚
さは $2 \mathrm{~mm}$ である。試験は恒温槽中で実施し、温度は- $10^{\circ} \mathrm{C} 、 0^{\circ} \mathrm{C} 、$ $10^{\circ} \mathrm{C} 、 20^{\circ} \mathrm{C} 、 30^{\circ} \mathrm{C} 、 40^{\circ} \mathrm{C}$ の 6 水準で評価した。最大せん断ひずみ は $100 \%$ 、加力速度は $0.33 \mathrm{~Hz}$ 、加力波形は正弦波とし、3 サイクル 目のせん断弾性率 $G_{\mathrm{eq}}$ とエネルギー吸収量 $\Delta W$ を用いて温度依存 性を決定した。温度依存性評価は、3 サイクルの繰返しで加力回 数は少ない。そのため、物性パラメータ $\beta_{T} 、 \theta_{T}$ は、疲労による剛 性低下の効果を無視 $\left(\Xi_{\mathrm{e}}=\Xi_{\mathrm{p}}=1\right)$ した時刻歷応答解析モデル $(2.10)$ (2.14) と、せん断弾性率 $G_{\text {eq }}$ とエネルギー吸収量 $\Delta W$ の温度依存試 験結果が一致するように決定した。また、実験データは $40^{\circ} \mathrm{C}$ まで のデータしか取得できなかったため、高温の領域については、外 挿による予測值となる。図2、3 亿同定結果を示す。図 2 は、疲 労を考慮せず、温度上昇のみによる剛性低下の効果を考慮した時 刻歴応答解析モデルにおける、各温度でのせん断応力一せん断ひ ずみ関係を表す。温度上昇と共にエネルギー吸収量が低下してい る様子がわかる。図 3 は、せん断弾性率 $G_{\mathrm{eq}}$ とエネルギー吸収量 $\Delta W$ について、せん断サンプルによるせん断加力試験の結果と、温度 上昇による岡性低下の効果を考慮した時刻歴応答解析モデルの 比較結果を表す。縦軸は、温度 $20^{\circ} \mathrm{C}$ での值 $G_{\mathrm{eq}}\left(20^{\circ} \mathrm{C}\right) 、 \Delta W\left(20^{\circ} \mathrm{C}\right)$ でそれぞれ規格化している。 $40^{\circ} \mathrm{C}$ までは高い精度で、実験結果と 時刻歴応答解析モデルの結果が一致している様子がわかる。本研 究では、加力の発熱による温度上昇に起因する剛性低下と、雾囲 気温度を制御することによる温度上昇に起因する剛性低下は、同 じであると仮定している。しかしながら、両者は必ずしも同一と は限らず、その妥当性検証は別途必要であると考えられる。

(3) $\boldsymbol{\beta}_{e} 、 \boldsymbol{\theta}_{e} 、 \boldsymbol{\beta}_{p} 、 \boldsymbol{\theta}_{p}$ の決定 : 4 ．2 節で述べる最大せん断ひずみ $200 \%$ の大変形繰返し試験より、得られたせん断弾性率 $G_{\mathrm{eq}}$ とエネルギ 一吸収量 $\Delta W$ の繰り返し回数依存性を調べる。その結果と、温度 上昇と疲労による剛性低下を考慮した時刻歴応答解析モデル (2.10) (2.14)が一致するように、 $\beta_{e} 、 \theta_{e} 、 \beta_{p} 、 \theta_{p}$ を決定する。復元 モデルにおける温度上昇予測式については 5 章で述べるが、ここ では積層ゴム表面の温度上昇の実験データを直接用いた。図 4、5 に、物性パラメータ值の同定結果を示す。図4、5 ともに、最大 せん断ひずみ $200 \%$ で 50 サイクルの繰返し加力を与えた場合の結 果を示した。図 4 は、せん断応力一せん断ひずみ曲線であり、温 度上昇の効果を考慮した場合としない場合、両方の結果を示した。 図 5 は、せん断弾性率 $G_{\mathrm{eq}}$ と $\Delta W$ の繰返し加力による変化であり、 縦軸は、3サイクル目での值 $G_{\mathrm{eq}}(3 \mathrm{cyc}$.)、 $\Delta W$ (3cyc.) でそれぞれ規 格化している。いずれの図からも、剛性やエネルギー吸収量が 徐々に低下している様子がわかる。また、図 5 からわかるように、 時刻歴応答解析モデルが実験結果を高い精度で再現できている 様子がわかる。

表 1 内部ゴムの物性パラメータ值(力学特性)

\begin{tabular}{cccccc}
\hline \hline $\begin{array}{c}C_{10} \\
\left(\mathrm{~N} / \mathrm{mm}^{2}\right)\end{array}$ & $\begin{array}{c}C_{20} \\
\left(\mathrm{~N} / \mathrm{mm}^{2}\right)\end{array}$ & $\begin{array}{c}\kappa \\
\left(\mathrm{N} / \mathrm{mm}^{2}\right)\end{array}$ & $\begin{array}{c}g \\
\left(\mathrm{~N} / \mathrm{mm}^{2}\right)\end{array}$ & $\begin{array}{c}l \\
(-)\end{array}$ & \\
\hline 0.152 & 0.0025 & 1000 & 0.645 & 0.12 & \\
\hline \hline$\theta_{T}$ & $\beta_{T}$ & $\theta_{e}$ & $\beta_{e}$ & $\theta_{p}$ & $\beta_{p}$ \\
$(-)$ & $\left({ }^{\circ}\right)$ & $(-)$ & $\left(\mathrm{N} / \mathrm{mm}^{2}\right)$ & $(-)$ & $\left(\mathrm{N} / \mathrm{mm}^{2}\right)$ \\
\hline 0.24 & 46.5 & 0.85 & 60 & 0.92 & 60 \\
\hline \hline
\end{tabular}




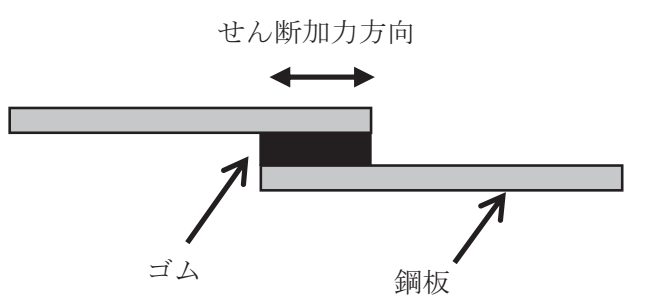

図 1 せん断試験片の断面図

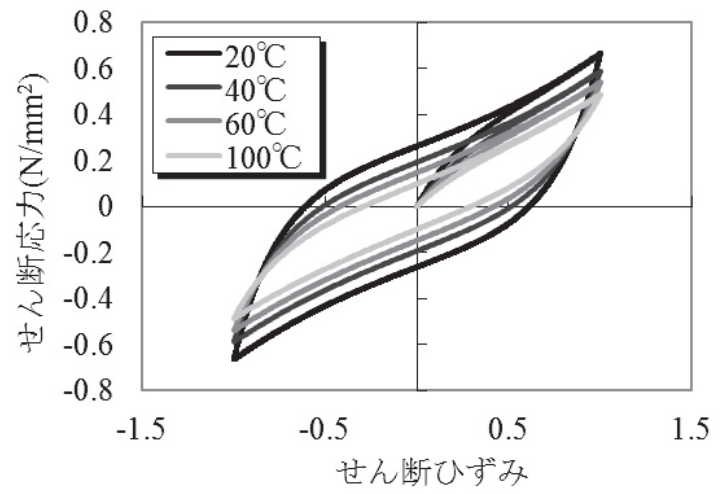

図 2 温度上昇による剛性低下を考慮した時刻歴応答解析モデルの せん断応力ーせん断ひずみ関係

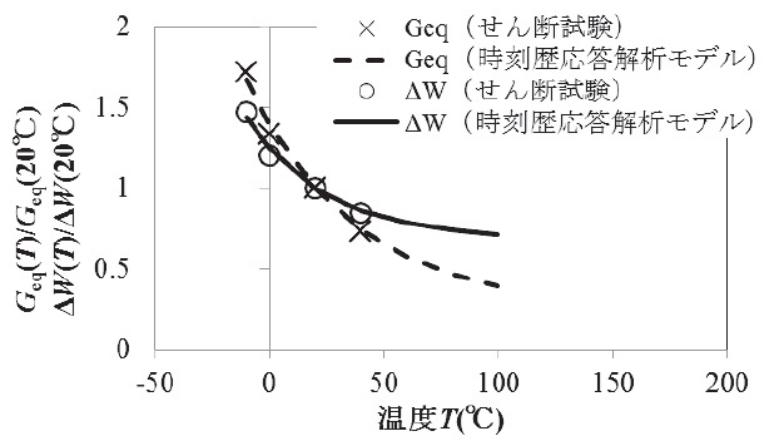

図 3 せん断サンプル試験と時刻歴応答解析モデルの 温度依存性の比較

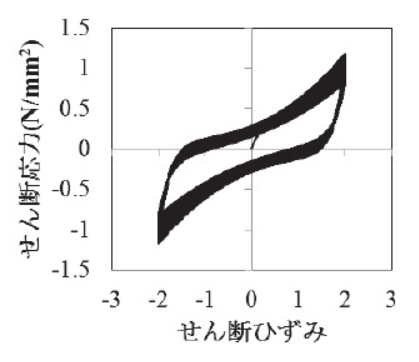

(a) 温度上昇考慮 (b) 温度一定

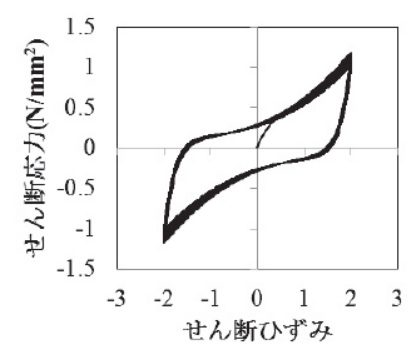

図 4 疲労と温度上昇による剛性低下を考慮した 時刻歴応答解析モデルのせん断応力ーせん断ひずみ関係

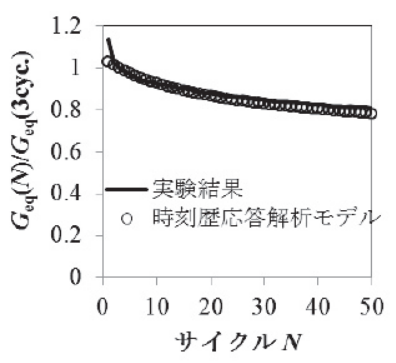

(a) $G_{\text {eq }}$ の変化

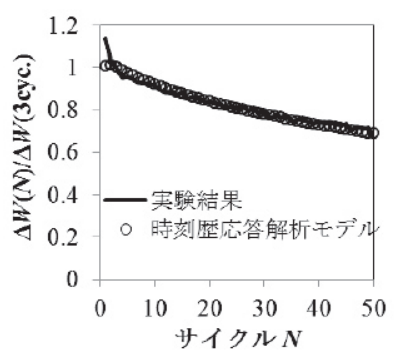

(b) $\Delta W$ の変化
図 5 温度上昇と疲労による剛性低下を考慮した 時刻歴応答解析モデルと実験結果の比較

\section{4. 熱-構造の連成 FEM 解析}

本章では、2 章にて提案した高減衰ゴムの材料構成則(2.2) (2.9) を用い、「疲労」や「温度上昇」による剛性低下の効果を考慮した、 熱一構造の連成 FEM 解析モデルの詳細を述べる。

\section{1 解析モデルの概要}

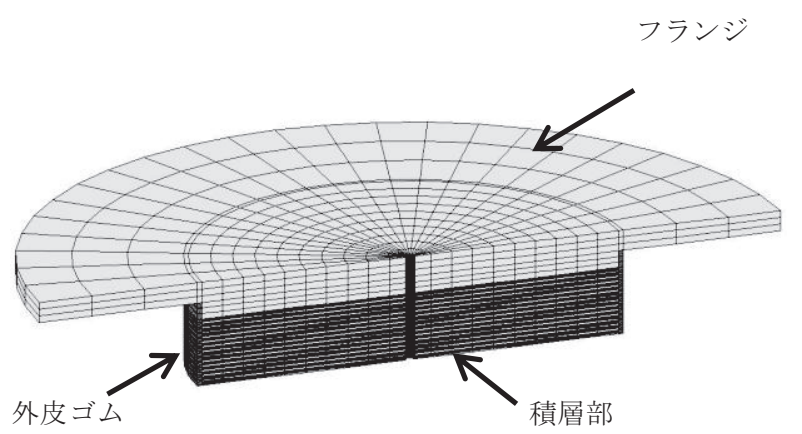

図 6 熱-構造の連成 FEM 解析モデル(1/4 モデル)

本研究では、解析ソフトとして MSC.MARC を利用した。構成則 (2.2)〜(2.9)の組み込みには、MSC.MARC に用意されているユーザ ーサブルーチン「HYPELA2」17)を用いた。本研究の解析に用いた 積層ゴムの形状は、4．2 節で述べる実験結果との比較対象である 大変形繰返し試験における試験体形状と同一とした。解析モデルの 形状を図 6 に示寸。図 6 からわかるように、解析モデルは鏡映対称 性と軸対称性を考慮した $1 / 4$ モデルとした。今回の解析は、主に積 層ゴムの水平方向の特性に着目しており、鉛直の分割数は積層ゴム の水平特性へ与える影響が小さい。このため、計算効率等も考慮し て、内部ゴム 1 層・内部鋼板 1 層ともに、鉛直方向には要素分割し ていない。使用要素については、内部ゴムは 6 面体 8 節点要素、内 部鋼板は 6 面体 8 節点の一様次数低減積分要素とした。

力学特性について、高減衰ゴム材料を想定した内部ゴムの構成則 については、上述の通り式(2.2)〜 (2.9)とし、物性パラメータは表 1 のものを用いた。外皮ゴムの力学特性については、式(4.1)で表され ているように、解析ソフトMSC.MARC に組み込まれている Neo-Hookean 型のエネルギー関数である、

$$
W=C\left(\bar{I}_{1}-3\right)+\frac{9}{2} k\left(I_{3}{ }^{1 / 6}-1\right)^{2}
$$

を用いた。物性パラメータ $C 、 k$ の值はそれぞれ、 $C=0.2 \mathrm{~N} / \mathrm{mm}^{2}$ 、 $k=1000 \mathrm{~N} / \mathrm{mm}^{2}$ とした。 $k$ は体積弾性率を表す。内部鋼板については 
一般構造用鋼構造部材 SS400 を想定した完全弾性体を仮定した。材 料パラメータは鋼構造設計基準 ${ }^{20)}$ の值を用い、ヤング率は $205000 \mathrm{~N} / \mathrm{mm}^{2}$ 、ポアソン比は 0.3 とした。

熱力学特性については、表 2 に示した物性パラメータ值を用いた。 内部ゴムと外皮ゴムに関しては、加硫ゴムの実測結果より得られた データを用いた。内部鋼板とフランジ(ともに SS400)については、 文献 21)のものを用いた。

表 2 物性パラメータ(熱力学特性)

\begin{tabular}{|c|c|c|c|}
\hline & $\begin{array}{c}\text { 密度 } \\
\left(\mathrm{kg} / \mathrm{m}^{3}\right)\end{array}$ & $\begin{array}{c}\text { 比熱 } \\
(\mathrm{J} / \mathrm{kg} \cdot \mathrm{K})\end{array}$ & $\begin{array}{c}\text { 熱伝導率 } \\
(\mathrm{W} / \mathrm{m} \cdot \mathrm{K})\end{array}$ \\
\hline \hline 内部ゴム & $1.15 \times 10^{3}$ & $1.45 \times 10^{3}$ & 0.310 \\
\hline 外皮ゴム & $1.15 \times 10^{3}$ & $1.88 \times 10^{3}$ & 0.289 \\
\hline 内部鋼板、フランジ(SS400) & $7.86 \times 10^{3}$ & $4.73 \times 10^{2}$ & 51.6 \\
\hline
\end{tabular}

発熱量に関しては、内部ゴムの単位体積当たりの塑性仕事量 $\Delta W$ が全て発熱のエネルギーに変換されると仮定した。式(2.6)において、

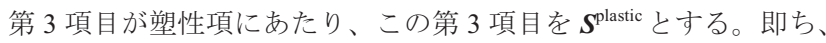

$$
\boldsymbol{S}^{\text {plastic }}=2 g \Xi_{p} F(T) \int_{0}^{L} \frac{\mathrm{d}}{\mathrm{d} L^{\prime}}\left(\frac{\partial \bar{W}_{0}}{\partial \boldsymbol{C}}\right) e^{-\left(L-L^{\prime}\right) /} \mathrm{d} L^{\prime}
$$

としたとき、 $S^{\text {plastic }}$ は第 2Piola-Kirchhoff 応力の塑性による成分を表 す。第 2Piola-Kirchhoff 応力は Green-Lagrange ひずみ $\boldsymbol{E}$ と共役な関 係にあるため、単位体積当たりの塑性仕事量 $\Delta W$ は以下で与えられ る。

$$
\Delta W=\frac{1}{2} \int \boldsymbol{S}^{\text {plastic }}: \mathrm{d} \boldsymbol{E}=\frac{1}{4} \int \boldsymbol{S}^{\text {plastic }}: \mathrm{d} \boldsymbol{C}
$$

1 サイクルの加力におけるせん断応力-せん断ひずみ曲線のループの 面積は、 1 サイクルにおける式(4.3)の $\Delta W$ に一致する。式(4.3)で与 えられる塑性仕事量を各インクリメント、各要素の積分点で計算し、 発熱量に変換して熱伝導を連成して解く。

\section{2 熱伝達係数の決定}

繰返し変形下では、塑性変形によるゴムの発熱エネルギーによっ て内部ゴムの温度が上昇するが、この熱エネルギーは上下フラン ジ・内部鋼板の温度上昇や、積層ゴム側面からの放熱によるエネル ギー散逸にも使われる。上下フランジや内部鋼板の温度上昇に使わ れる熱エネルギー量は、鋼板やゴムの密度、比熱、熱伝導率といっ たいわゆる物性值わかっていれば予測は容易である。しかしながら、 積層ゴム表面からの熱の散逸は、熱伝達現象であり、物性值のみか らの予測はできず、積層ゴムと外気間の熱伝達係数の情報が必要と なる。そこで本節では、内部ゴムが温度上昇を示すような繰返し加 力実験結果をもとに、積層ゴムと外気間の熱伝達係数を決定する。 具体的には、高減衰積層ゴムの繰返し加力実験における積層ゴム表 面の温度測定結果と、熱伝導 FEM におけるゴム表面の温度の解析 結果が一致するように、積層ゴムと外気間の熱伝達係数を決定する。 比較対象の実験データは、高減衰積層ゴムの動的な大変形繰返し加 力試験及び動的な風応答加力試験とした。動的な大変形繰返し加力 試験における試験条件を表 3 に、動的な風応答加力試験における試 験条件を表 4 に示す。両者ともに試験体形状は同一である。試験体 の形状・性能を図 7 及び表 5 に示す。内部ゴムは、過去に筆者らに よって、変形履歴積分型の弾塑性構成則から導かれた時刻歴応答解
析モデル ${ }^{15)}$ の妥当性を確認した高減衰積層ゴム試験体におけるゴム 材料 $\left.{ }^{18)}, 19\right)$ と同一である。

FEM 解析モデルを図 8 に示す。モデルは、2 次元の軸対称モデル とした。試験機への取付けに用いる面盤もモデル化し、初期温度は 積層ゴム・面盤ともに全要素 $20^{\circ} \mathrm{C}$ とした。面盤・フランジ・外皮ゴ ムの表面は、温度 $20^{\circ} \mathrm{C}$ 外気との熱伝達とし、熱伝達係数は全ての 表面で一定とした。内部ゴムに与える発熱量は、それぞれの加力実 験から得られた単位時間当たりの吸収エネルギーとし、内部ゴムで 一様に発熱すると仮定した。一例として、周期 $3 \mathrm{sec} の$ 動的な大変形 繰返し実験から得られた、単位時間当たりのエネルギー吸収量の時 間変化の結果を図 9 に示す。せん断ひずみ $300 \%$ の繰返し加力にお いて、約 400 sec 後(約 130 サイクル加力後)に見られるエネルギー吸 収量の急激な立ち上がりは、疲労によって終局状態に達したことに よる影響である。

積層ゴムの表面温度上昇の実験結果と合うように熱伝達係数 $h$ を 決定した結果、 $h=15 \mathrm{~W} / \mathrm{m}^{2} \cdot \mathrm{K}$ となった。 $h=15 \mathrm{~W} / \mathrm{m}^{2} \cdot \mathrm{K}$ の時の積層 ゴム表面温度(サンプリング位置は積層ゴム中央部)の時間変化の実 験結果と解析結果の比較を図 10 に示寸。図 10 からわかるように、 $h=15 \mathrm{~W} / \mathrm{m}^{2} \cdot \mathrm{K}$ とした場合、発熱量に依らず実験結果における温度上 昇を概ね再現できていることがわかる。以後、外気との熱伝達には、 $h=15 \mathrm{~W} / \mathrm{m}^{2} \cdot \mathrm{K}$ を用いることとする。図 11 は加力試験条件 $\tau_{\mathrm{s}} \pm \tau_{\mathrm{d}}=0.4$ $\pm 0.4 \mathrm{~N} / \mathrm{mm}^{2}$ の風応答の場合の $1 、 2 、 3$ 時間後の温度コンター図であ る。表 4 に示したように、風応答試験に関しては、2 時間加力後に 水平加力を 0 として 1 時間放置している。放置状態では発熱量=0 で あるため、 2 時間後に比べて、 3 時間後に温度が低下している様子が わかる。図 12 には、積層ゴム高さ方向(図 8 の A-A'断面)及び水平方 向(図 8 の B-B'断面)の、加力後 2 時間後の温度分布を示寸。図 12 からわかるように、温度勾配は積層ゴムの水平方向よりも高さ方向 に大きい。このことから、積層ゴムのゴム表面からの熱の散逸より も、フランジへの熱の散逸が大きいことがわかる。

表 3 大変形繰返し試験の加力条件

\begin{tabular}{|c|c|c|c|c|}
\hline $\begin{array}{c}\text { 面圧 } \\
\left(\mathrm{N} / \mathrm{mm}^{2}\right)\end{array}$ & $\begin{array}{c}\text { 最大せん断ひずみ } \\
(\%)\end{array}$ & 加力波形 & $\begin{array}{c}\text { 加力速度 } \\
(\mathrm{Hz})\end{array}$ & $\begin{array}{c}\text { 加力回数 } \\
(\text { 回 })\end{array}$ \\
\hline \hline 15 & 200 & 正弦波 & 0.33 & 500 \\
\hline 15 & 300 & 正弦波 & 0.33 & 140 \\
\hline
\end{tabular}

表 4 風応答試験の加力条件

\begin{tabular}{|c|c|c|c|c|}
\hline $\begin{array}{c}\text { せん断応力 } \\
\text { 静的応力士動的応力 } \\
\tau_{\mathrm{s}} \pm \tau_{\mathrm{d}}\left(\mathrm{N} / \mathrm{mm}^{2}\right)\end{array}$ & $\begin{array}{c}\text { 面圧 } \\
\left(\mathrm{N} / \mathrm{mm}^{2}\right)\end{array}$ & $\begin{array}{c}\text { 加力速度 } \\
(\mathrm{Hz})\end{array}$ & $\begin{array}{c}\text { 加力時間 } \\
\text { (hour) }\end{array}$ & $\begin{array}{c}\text { 加力後 } \\
\text { 放置時間 } \\
\text { (hour) }\end{array}$ \\
\hline \hline $0.2 \pm 0.05$ & 15 & 0.33 & 2 & 1 \\
\hline $0.2 \pm 0.1$ & 15 & 0.33 & 2 & 1 \\
\hline $0.2 \pm 0.2$ & 15 & 0.33 & 2 & 1 \\
\hline $0.4 \pm 0.1$ & 15 & 0.33 & 2 & 1 \\
\hline $0.4 \pm 0.2$ & 15 & 0.33 & 2 & 1 \\
\hline $0.4 \pm 0.4$ & 15 & 0.33 & 2 & 1 \\
\hline
\end{tabular}




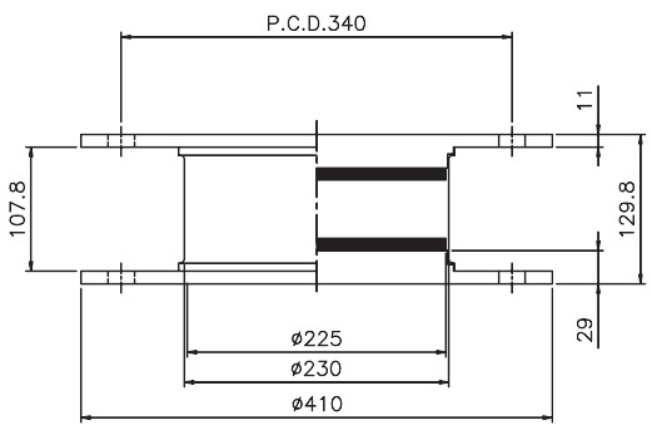

図 7 試験体の形状

表 5 試験体形状・性能一覧

\begin{tabular}{|c|c|}
\hline ゴム外径 $(\mathrm{mm})$ & 225 \\
\hline ゴム内径 $(\mathrm{mm})$ & 0 \\
\hline ゴム 1 層厚さ $(\mathrm{mm})$ & 1.6 \\
\hline ゴム積層数 & 28 \\
\hline 内部鋼板 1 層厚さ $(\mathrm{mm})$ & 1.0 \\
\hline 1 次形状係数 $S_{1}$ & 35.2 \\
\hline 2 次形状係数 $S_{2}$ & 5.02 \\
\hline せん断弾性率 $\left(\mathrm{N} / \mathrm{mm}^{2}\right)$ & 0.620 \\
\hline 鉛直剛性 $(\mathrm{kN} / \mathrm{mm})$ & 1230 \\
\hline 水平剛性 $(\mathrm{kN} / \mathrm{mm})$ & 0.550 \\
\hline 外皮ゴム厚さ $(\mathrm{mm})$ & 2.5 \\
\hline
\end{tabular}

※ せん断弾性率と水平剛性はせん断ひずみ $100 \%$ 時の性能を表し、鉛直剛性 はせん断ひずみ $0 \%$ の状態で、基準面圧 $\pm 30 \%$ の変動荷重を与えた場合の性能 を表す。

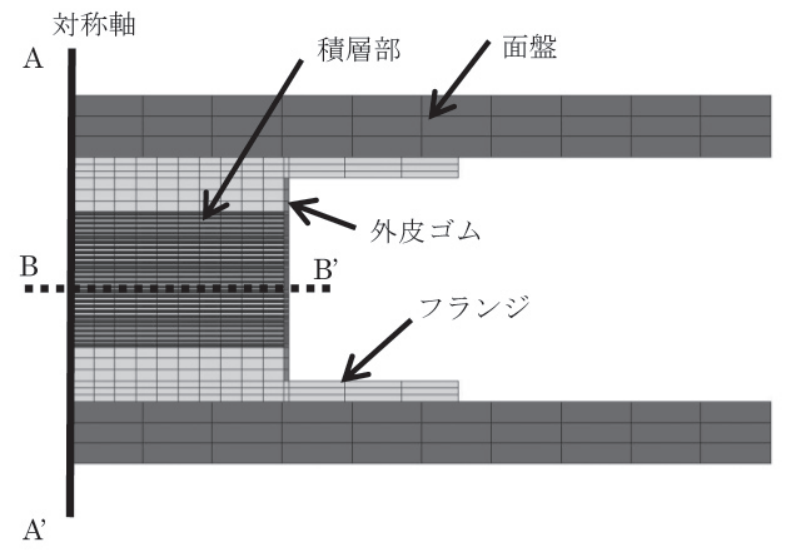

図 8 熱伝導 FEM 解析モデル(軸対称モデル)

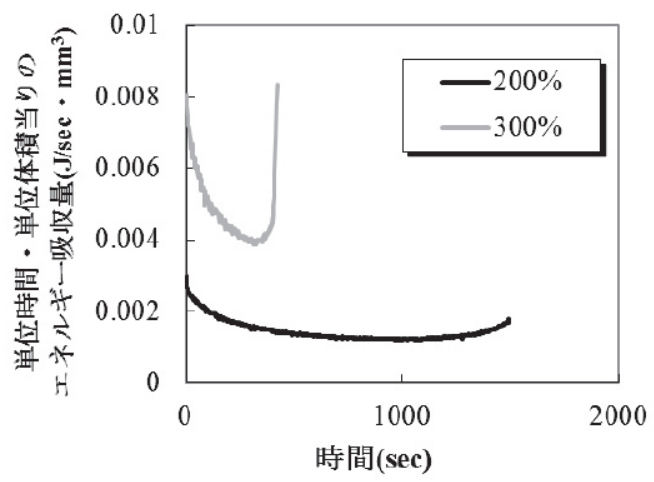

図 9 大変形繰返し試験におけるエネルギー吸収量 $\Delta W$ の時間変化

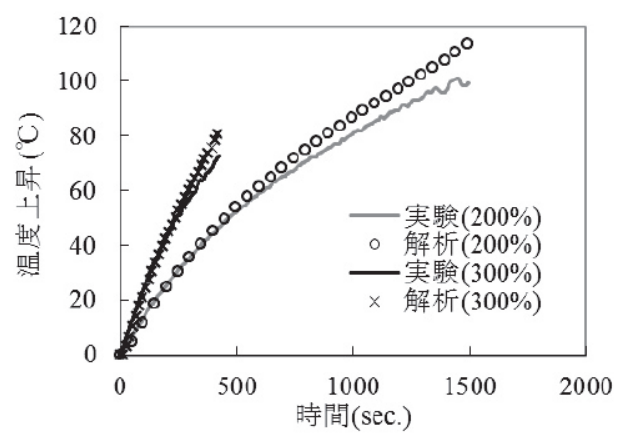

(a) 大変形繰返し試験

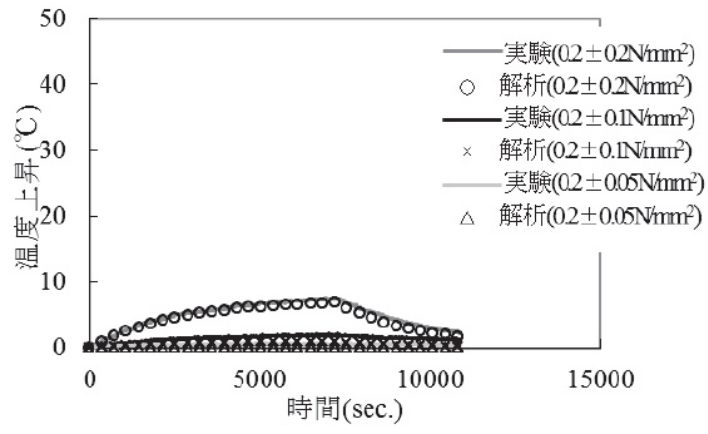

(b) 風応答試験( 静的応力 $\tau_{\mathrm{s}}=0.2 \mathrm{~N} / \mathrm{mm}^{2}$ )

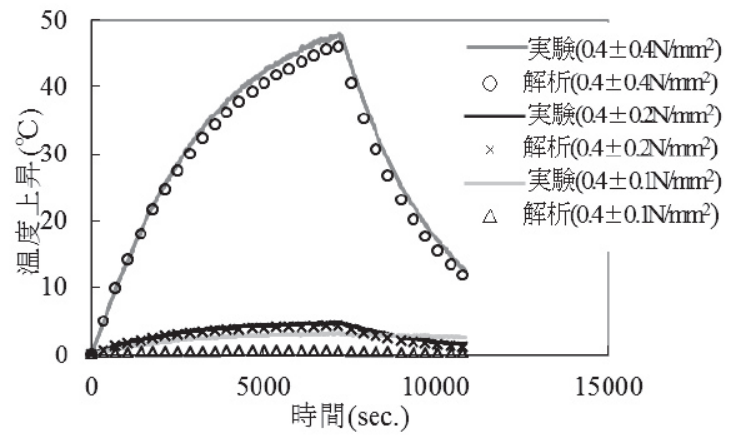

(c) 風応答試験(静的応力 $\tau_{\mathrm{s}}=0.4 \mathrm{~N} / \mathrm{mm}^{2}$ )

図 10 積層ゴム表面温度の実験結果と解析結果の比較
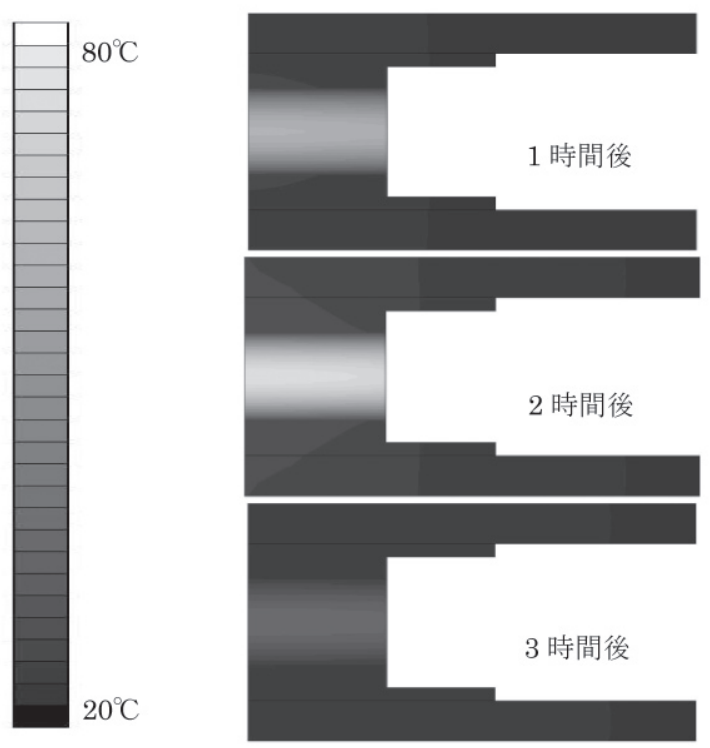

図 $11 \quad 1 、 2 、 3$ 時間後の温度分布

(風応答試験 $\tau_{\mathrm{s}} \pm \tau_{\mathrm{d}}=0.4 \pm 0.4 \mathrm{~N} / \mathrm{mm}^{2}$ ) 


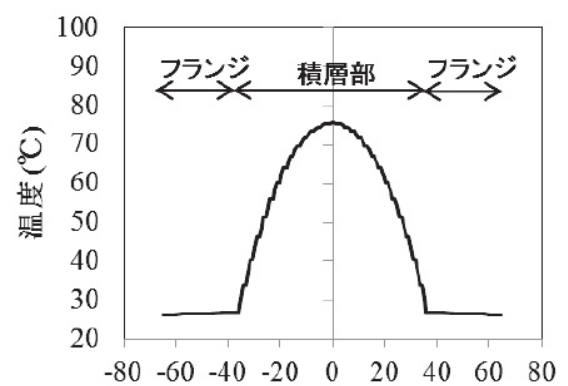

積層ゴム中心からの高さ位置 $(\mathbf{m m})$

(a) 高さ方向(図 8 の A-A'断面)

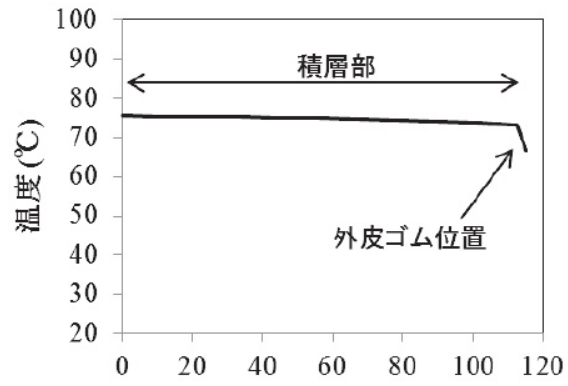

積層ゴム中心からの水平位置 $(\mathbf{m m})$

(b) 水平方向(図 8 の B-B'断面)

図 122 時間後の積層ゴム内部の温度勾配

(風応答試験 $\tau_{\mathrm{s}} \pm \tau_{\mathrm{d}}=0.4 \pm 0.4 \mathrm{~N} / \mathrm{mm}^{2}$ )

\section{3 熱-構造の連成 FEM 解析結果}

4. 2 節にて決定した熱伝達係数を用い、熱-構造連成 FEM 解析 を行った結果を以下に示す。実施した加力ケースは、表 3 に示した 最大せん断ひずみ $200 \%$ の加力条件で、50 サイクル加力した。初期 温度は $20^{\circ} \mathrm{C}$ とている。

図 13 に、せん断応力一せん断ひずみ関係の結果を示す。ゴムの示 すハードニング特性については、解析結果の方が若干大きいが、概 放実験結果と解析結果が一致している様子がわかる。図 14 に、繰返 し加力による、等価剛性、等価粘性減衰定数、エネルギー吸収量、 積層ゴム表面温度の変化について、実験結果と解析結果の比較を示 す。等価剛性 $K_{\mathrm{h} 、}$ 等価粘性減衰定数 $H_{\mathrm{eq}}$ 、エネルギー吸収量 $\Delta W$ に ついては、縦軸は、3 サイクル目の值で規格化している。この結果 から、高減衰ゴムの材料構成則(2.2) (2.9)の有用性が確認される。 図 14 からわかるように、高い精度で実験結果と解析結果が一致し ている様子がわかる。図 13、図 14 の実験結果において、1 サイク ル目と 2 サイクル目での剛性低下が顕著であり、解析結果と比べて も大きいことが確認される。このように、剛性低下が 1 サイクル目 と 2 サイクル目の間で特に大きくなり、2 サイクル目以降は比較的 緩やかに剛性が低下寸るのは、高減衰ゴムの特徵でもある。その特 性は、本論文で提案している解析モデルでは再現できない。このよ うな特性も再現できるように解析モデルを修正することも可能であ る。しかしながら、本研究は多数回繰り返した場合の特性変化に着 目しており、解析モデルをできるだけ単純化する目的で、今回は 1 サイクル目と 2 サイクル目の顕著な剛性低下は無視した。図 15 に、 FEM 解析結果のコンター図の一例として、50 サイクル目、200\% せん断変形時の温度分布を示す。

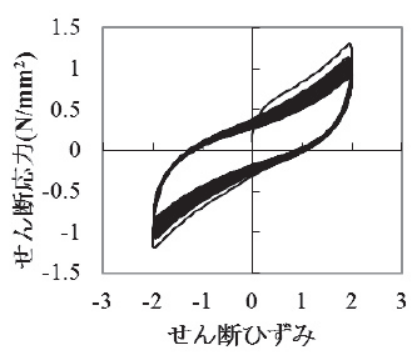

(a) 実験

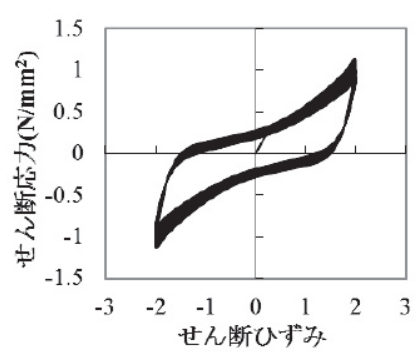

(b) 解析
図 13 せん断応力 - せん断ひずみ関係の実験と解析の比較
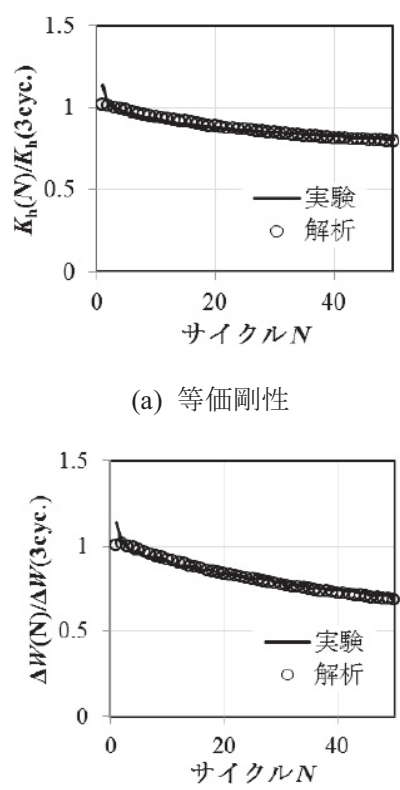

(c) エネルギー吸収量 (a) 等価剛性

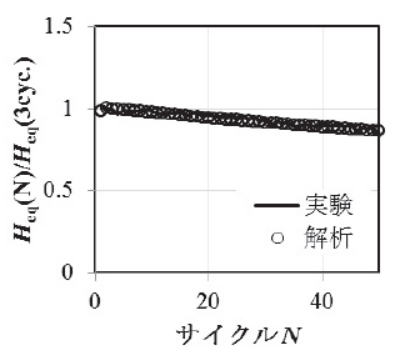

(b) 等価粘性減衰定数

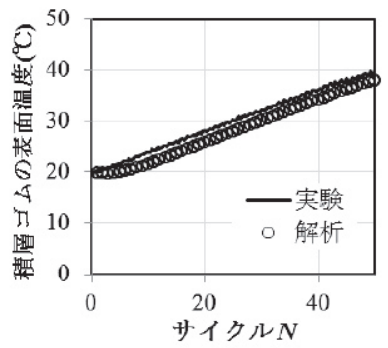

(d) 積層ゴム表面の温度上昇
図 14 等価剛性、等価粘性減衰定数、エネルギー吸収量、 積層ゴム表面温度の実験と解析の比較

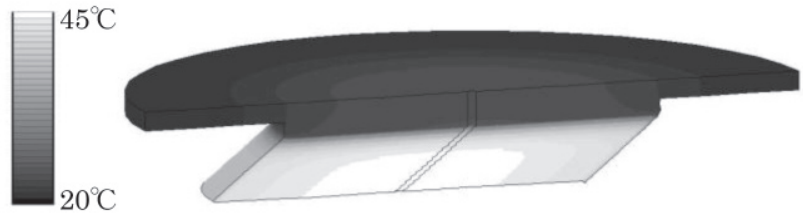

図 15 積層ゴムの変形状態及び内部の温度分布

\section{5. 時刻歴応答解析モデルにおける温度上昇予測式}

本章では、様々な形状の積層ゴムに対し、内部ゴムが時間に依ら ず一定に発熱する場合において、積層ゴム内部の体積平均温度の時 間変化を FEM により解析する。その結果をもとに、式(2.15)の妥当 性を検証し、 $\alpha$ と $T_{\infty}$ のサイズ・形状依存性を決定する。内部発熱量 が時間に対し一定とすると、式(2.15)から、積層ゴムの内部温度 $T$ の時間依存性は以下の通り導かれる。

$$
T(t)=T_{0}+T_{\infty}\left(1-e^{-\alpha q t}\right)
$$

本研究では、単位時間・単位体積当たりの内部発熱量を $5 \times 10^{-4} \mathrm{~J} /\left(\mathrm{sec} \cdot \mathrm{mm}^{3}\right)$ として解析した。この值は、4．２節の実験に用 いた高減衰ゴム材料において、加力速度 $0.33 \mathrm{~Hz}$ の正弦波、せん断ひ ずみ $150 \%$ 程度で繰返し加力した場合の発熱量に相当する。FEM に 
よる内部ゴムの体積平均温度の時間変化を、最小二乗法により式 (5.1)で近似し、パラメータ $\alpha$ と $T_{\infty}$ を決定する。FEM 解析モデルを図 16 に示した。外気温度は $0^{\circ} \mathrm{C}$ と、外気との熱伝達係数は 4.2 節 にて決定した值 $15 \mathrm{~W} / \mathrm{m}^{2} \cdot \mathrm{K}$ とした。形状依存性に関する具体的な 変数は、「積層ゴムの外径 $D\lrcorner$ 、「2 次形状係数 $\left.S_{2}\right\rfloor$ 、「内部鋼板厚さ $T_{\mathrm{s}}$ とゴム 1 層厚さ $T_{\mathrm{r}}$ の比 $R\left(=T_{\mathrm{s}} / T_{\mathrm{r}}\right) 」$ とした。解析を行った形状の 一覧を、表 6 にまとめた。表 6 におけるサイズ值は、実用的な積層 ゴムのサイズ・形状を網羅できるように選定した。

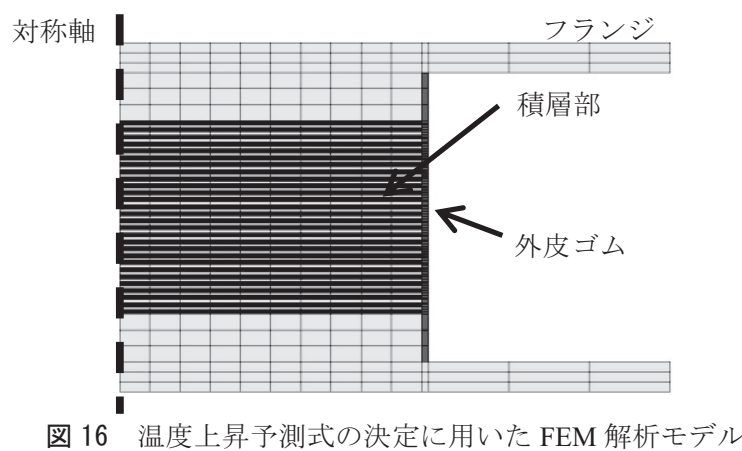

FEM 解析により得られた体積平均温度 $T$ のサイズ・構造依存性の 結果を図 17 に示す。図 17 からわかるように、「積層ゴムの外径 $D 」$ 、 $\left\lceil\right.$ 内部鋼板厚さ $T_{\mathrm{s}}$ とゴム 1 層厚さ $T_{\mathrm{r}}$ の比 $R\left(=T_{\mathrm{s}} / T_{\mathrm{r}}\right) 」$ に対する依存 性は大きいが、「2 次形状係数 $S_{2}$ 」に対する依存性は小さい。しかし ながら、単位時間・単位体積当たりの内部発熱量を $5 \times 10^{-5} \mathrm{~J} / \mathrm{sec} \cdot \mathrm{mm}^{3}$ として解析した場合(図 18)、「2 次形状係数 $S_{2} 」$ に対寸る依存性は大 きいことがわかる。風荷重による加力などにおいては、図 18 に示し たように数時間にわたって温度が徐々に上昇する。このため、風応 答等も考慮できる解析モデルを想定し、「2 次形状係数 $S_{2} 」$ に対寸る
依存性も考慮する。このように、長周期や風荷重のような時間スケ 一ルの違いによっても、サイズ・形状の依存性が大きくなる場合が あることがわかる。また、本論文では記載していないが、外皮ゴム 厚さやフランジ厚さに対する依存性も調べた。実用的な積層ゴムの 形状の範囲では、それらの影響は小さいことを確認している。

体積平均温度 $T$ の時間変化の解析結果と、式(5.1)で近似した結果 の Case-I、II での比較例を図 19 に示す。式(5.1)にて高精度で近似で きており、式(2.15)の仮定は妥当であると言える。

「積層ゴムの外径 $D 」 、 「 2$ 次形状係数 $\left.S_{2}\right\rfloor$ 、「内部鋼板厚さ $T_{\mathrm{s}}$ とゴ 厶 1 層厚さ $T_{\mathrm{r}}$ の比 $R\left(=T_{\mathrm{s}} / T_{\mathrm{r}}\right)$ 」を変化させた様々な形状について解 析を行い、 $\alpha$ と $T_{\infty}$ を同定した結果を表 7 に示す。表 7 の結果から、 $\alpha$ と $T_{\infty}$ の $D 、 S_{2} 、 R$ に対寸る依存性に合うように決定した依存式(近 似式)を、以下の通り仮定寸る。

$$
\begin{aligned}
& \alpha=A_{1} S_{2}\left(A_{2}-R\right)\left(\frac{1}{D^{2}}+\frac{1}{A_{3} D}\right) \\
& T_{\infty}=B_{1} q\left(\frac{B_{2}}{S_{2}}-\frac{1}{S_{2}^{2}}\right)\left(B_{3}-R\right)\left(D^{2}+B_{4} D\right)
\end{aligned}
$$

$A_{1} 、 A_{2} 、 A_{3} 、 B_{1} 、 B_{2} 、 B_{3} 、 B_{4}$ は、パラメータである。FEM 解析結果 と近似式(5.2)、(5.3)が合うように、パラメータ $A_{1} 、 A_{2} 、 A_{3} 、 B_{1} 、 B_{2}$ 、 $B_{3} 、 B_{4}$ を同定した結果を表 8 に、近似式(5.2)、(5.3) と FEM 解析結果 の比較を図 20 に示寸。近似式(5.2)、(5.3)にて FEM 解析から得られ たサイズ・構造依存性を高い精度で表現できていることがわかる。

4.2節で示した試験体でのせん断ひずみ $200 \%$ 、50 サイクルの 大変形繰返し試験に対し、温度上昇予測式を適用した時刻歴応答解 析モデルにおけるせん断応力一せん断ひずみ関係の結果を図 21 に 示す。表 5 より、4.2 節の試験体においては、 $D=225 \mathrm{~mm} 、 S_{2}=5.02$ 、 $R=0.625$ である。図 13(a) と図 21 の比較からわかるように、実験結 果を高い精度で再現できていることがわかる。

表 6 解析を行ったモデル形状の一覧

\begin{tabular}{|c|c|c|c|c|c|c|c|c|}
\hline & Case-I & Case-II & Case-III & Case-IV & Case-V & Case-VI & Case-VII & Case-VIII \\
\hline \hline ヨ゙ム外径 $D(\mathrm{~mm})$ & 800 & $\mathbf{2 0 0}$ & $\mathbf{4 0 0}$ & $\mathbf{1 6 0 0}$ & 800 & 800 & 800 & 800 \\
\hline ت゙ム 1 層厚さ $T_{\mathrm{r}}(\mathrm{mm})$ & 5 & 1.25 & 2.5 & 10 & 5 & 5 & 5 & 5 \\
\hline ゴム積層数 & 32 & 32 & 32 & 32 & 64 & 16 & 32 & 32 \\
\hline ゴム総厚さ $(\mathrm{mm})$ & 160 & 40 & 80 & 320 & 320 & 80 & 160 & 160 \\
\hline 内部鋼板厚さ $T_{\mathrm{s}}(\mathrm{mm})$ & 4 & 1 & 2 & 8 & 4 & 4 & 3 & 5 \\
\hline 1 次形状係数 $S_{1}$ & 40 & 40 & 40 & 40 & 40 & 40 & 40 & 40 \\
\hline 2 次形状係数 $S_{2}$ & 5.0 & 5.0 & 5.0 & 5.0 & $\mathbf{2 . 5}$ & $\mathbf{1 0 . 0}$ & 5.0 & 5.0 \\
\hline$R\left(=T_{\mathrm{s}} T_{\mathrm{r}}\right)$ & 0.8 & 0.8 & 0.8 & 0.8 & 0.8 & 0.8 & $\mathbf{0 . 6}$ & $\mathbf{1 . 0}$ \\
\hline フランジ厚さ $(\mathrm{mm})$ & 32 & 8 & 16 & 64 & 32 & 32 & 32 & 32 \\
\hline フランジ外径 $(\mathrm{mm})$ & 1200 & 300 & 600 & 2400 & 1200 & 1200 & 1200 & 1200 \\
\hline 外皮ゴム厚さ $(\mathrm{mm})$ & 8 & 8 & 8 & 8 & 8 & 8 & 8 & 8 \\
\hline 備考 & 基本モデル & $D=200$ & $D=400$ & $D=1600$ & $S_{2}=2.5$ & $S_{2}=10.0$ & $R=0.6$ & $R=1.0$ \\
\hline
\end{tabular}

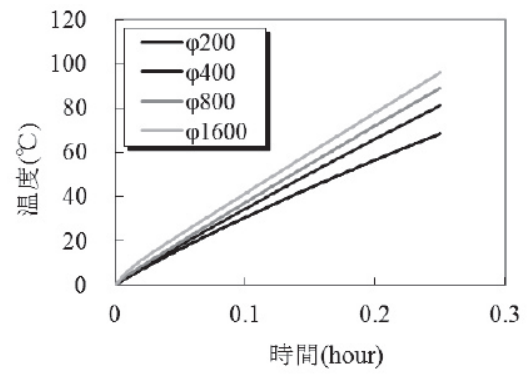

(a) $D$ 依存性

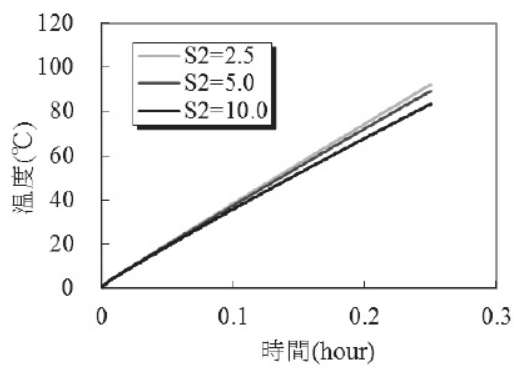

(b) $S_{2}$ 依存性

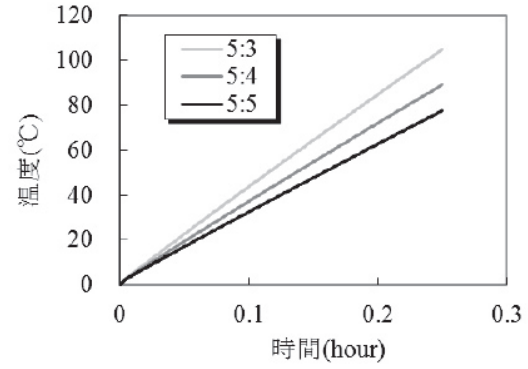

(b) $R$ 依存性

図 17 体積平均温度のサイズ・構造依存性 


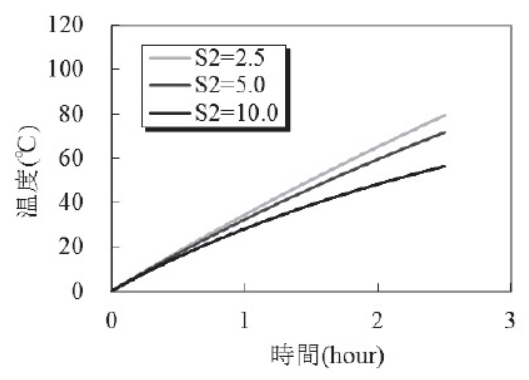

図 18 体積平均温度の $S_{2}$ 依存性

(内部発熱量 : $5 \times 10^{-5} \mathrm{~J} / \mathrm{sec} \cdot \mathrm{mm}^{3}$ )

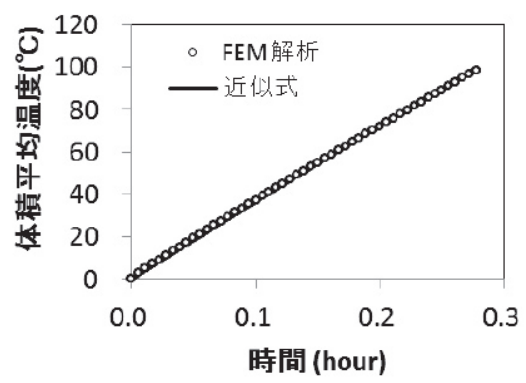

(a) Case-I $(D=800)$

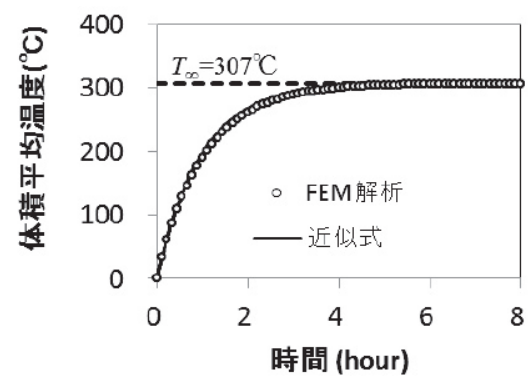

(b) Case-II $(D=200)$

図 19 体積平均温度の時間変化の FEM 解析と近似式の比較例

表 $7 \quad \alpha$ と $T_{\infty}$ の同定結果

\begin{tabular}{|c|c|c|c|c|c|c|c|c|}
\hline & Case-I & Case-II & Case-III & Case-IV & Case-V & Case-VI & Case-VII & Case-VIII \\
\hline \hline$\alpha\left(\mathrm{mm}^{3} / \mathrm{J}\right)$ & 0.0437 & 0.284 & 0.114 & 0.0175 & 0.0283 & 0.0899 & 0.0487 & 0.0401 \\
\hline$T_{\infty}\left({ }^{\circ} \mathrm{C}\right)$ & 2331 & 307 & 842 & 6248 & 3696 & 1084 & 2468 & 2210 \\
\hline
\end{tabular}

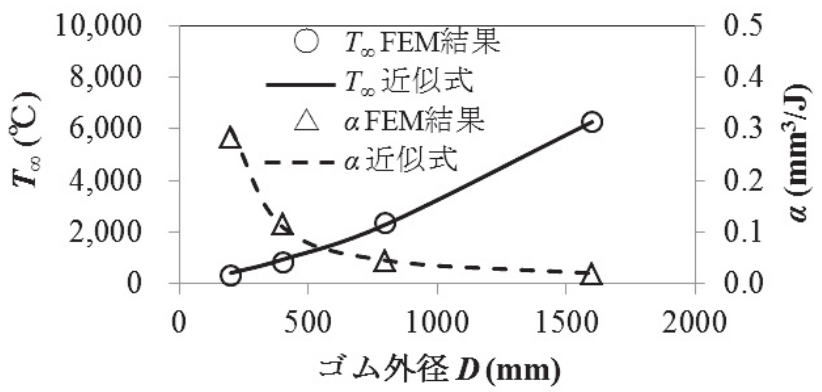

(a) $D$ 依存性

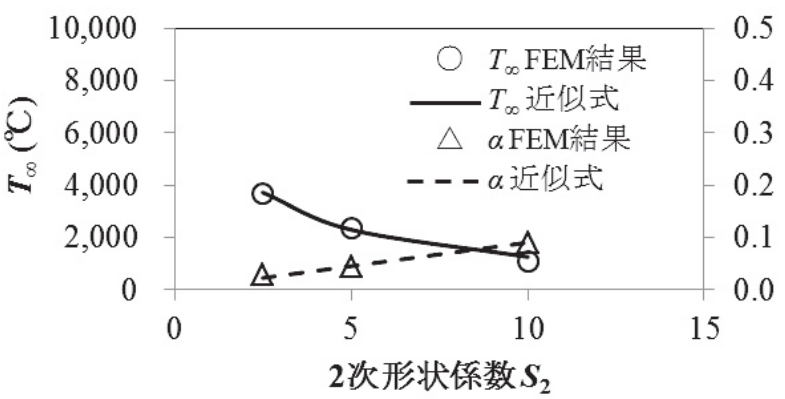

(b) $S_{2}$ 依存性

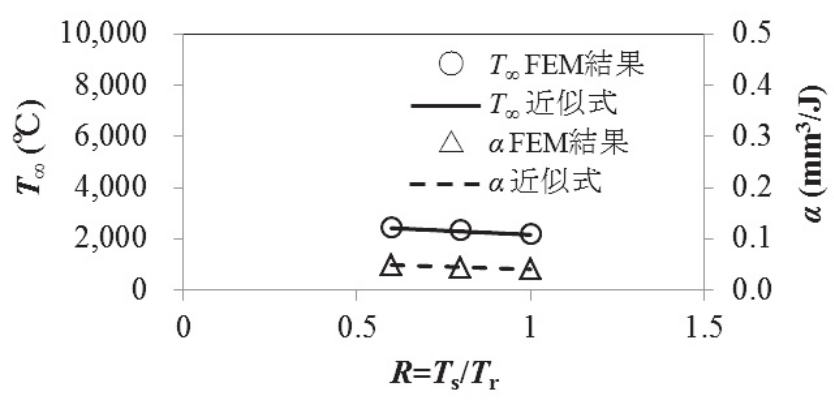

(c) $R$ 依存性

図 20 近似式と $\alpha 、 T_{\infty}$ の同定結果の比較

\begin{tabular}{cccc} 
表 8 & 近似式におけるパラメータ值の同定結果 \\
\hline \hline $\begin{array}{c}A_{1} \\
\left(\mathrm{~mm}^{3} / \mathrm{J}\right)\end{array}$ & $\begin{array}{c}A_{2} \\
(-)\end{array}$ & $\begin{array}{c}A_{3} \\
(\mathrm{~mm})\end{array}$ & \\
\hline 621 & 2.85 & 227 & \\
\hline \hline$B_{1}$ & $B_{2}$ & $B_{3}$ & $B_{4}$ \\
$\left(\mathrm{sec} \cdot \mathrm{mm} \cdot{ }^{\circ} \mathrm{C} / \mathrm{J}\right)$ & $(-)$ & $(-)$ & $(\mathrm{mm})$ \\
\hline 3.50 & 1.25 & 4.36 & 1380 \\
\hline \hline
\end{tabular}

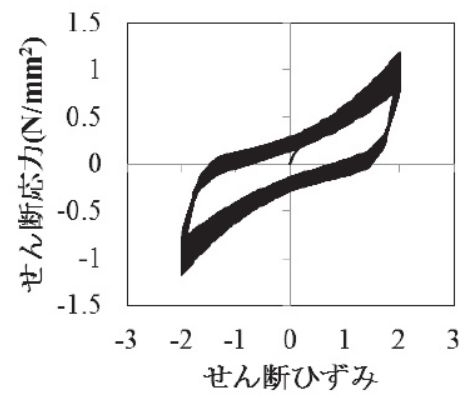

図 21 温度上昇予測式を適用した時刻歴応答解析モデルによる せん断応力 - せん断ひずみ関係の解析結果

\section{6. まとめ}

長周期地震動や風荷重を想定した多数回の変形繰返し変形を受け る高減衰積層ゴムの挙動の予測を目的として、熱一構造の連成 FEM 解析モデルと時刻歴応答解析モデルを提案した。前者においては、 特に重要となる高減衰ゴムの材料構成則を提案し、後者においては 提案した高減衰ゴム材料の構成則に対し単純せん断モデルへの縮退 化を行うことで、時刻歴応答解析モデルを提案した。これらのモデ ルは、高減衰積層ゴムの繰返し変形で問題となる、疲労や温度上昇 による剛性の低下を考慮に入れたモデルとなっている。

提案した 2 つ解析モデルにて、剛性や減衰の変化、積層ゴムの 温度上昇等、実験結果の再現性は確認され、有用性は十分にあると 考えられる。しかしながら、本研究にて新たに提案した高減衰ゴム の材料構成則と、時刻歴応答解析モデルの妥当性は、より詳細な検 証が必要と考えられる。例えば、温度上昇のサイズ効果については、 
FEM による予測のみであり、大口径サイズの積層ゴムの動的な加力 が困難である等の理由により、実験によるサイズ効果の確認はなさ れていない。大口径サイズの積層ゴムを含む、実験によるサイズ効 果の確認が今後の課題である。また、本研究における解析モデルの 適用範囲にも注意を要する。例えば、本研究におけるゴムの温度依 存評価は $40^{\circ} \mathrm{C}$ 以下でしか行っていない。それ以上の温度領域は外挿 による予測であるため、 $40^{\circ} \mathrm{C}$ 以上の領域におけるモデルの妥当性検 証は十分とは言えず、温度上昇が大きい場合には提案した解析モデ ルの適用に注意を要する。また、剛性低下の影響に関しては、温度 上昇と疲労の影響を分離してパラメータの同定を行っているが、そ の妥当性も確かとは言えない。これらの妥当性検証も今後の課題で ある。

\section{参考文献}

1）日本免震構造協会：時刻歴応答解析による免震建物の設計基準・同マニ ユアル及び設計例，大應, 2010.3

2) L. Mullins, Softening of rubber by deformation., Rubber Chemistry and Technology, 42, pp.339-362, 1969

3) 鳥井信吾, 室田伸夫, 山根尚志, 北村春幸, 高山峰夫, 太田雅己, 芳沢利 和：高減衰型積層ゴムの各種依存性を評価した解析手法と製品検查に関 寸る一考察, 日本建築学会技術報告集, 第 8 号, pp101-106, 1999.6

4) 長嶋一郎他：長周期地震動に対する実大免震部材の実験計画(その 1,2), 日本建築学会大会学術講演梗概集 B, pp651-654, 2011

5) 飯場正紀他 : 長周期地震動に対する免震部材の多数回繰返し実験(その 1 ９), 日本建築学会大会学術講演梗概集 B, pp655-672, 2011

6) 竹中康雄, 近藤明洋, 高岡栄治, 引田真規子, 北村春幸, 仲村崇仁: 積層ゴ 厶の熱・ 力学連成挙動に関する実験的研究, 日本建築学会構造系論文集, 第 74 巻, 第 646 号, pp.2245-2253, 2009.12

7) 本間友規他 : 大変形繰返し変形を受ける積層ゴム支承の熱・力学連成挙 動に関する研究(その 9 11), 日本建築学会大会学術講演梗概集 B, pp.397-402, 2008

8) 北村春幸, 早川修平, 竹中康雄, 高岡栄治, 室田伸夫：高減衰ゴムの熱・ 力学的連成挙動の免震建物応答一の影響評価, 日本建築学会構造系論文
集, 第 75 巻, 第 655 号, pp.1635-1644, 2010.9

9）仲村崇仁，竹中康雄，池永雅良，鈴木雅靖，河内山修，吉川和秀，金子修 平：高層免震建物の風応答における LRB の健全性に関する研究(その 1 ２), 日本建築学会大会学術講演梗概集 B, pp.489-492, 2003.9

10) 河内山修, 仲村崇仁, 金子修平, 和田章: 風応答における高層免震建物の LRB の健全性評価, MENSHIN, 47, pp.47-53, 2005.2

11) 加藤秀章, 森隆浩, 室田伸夫：高減衰系積層ゴムの風荷重応答に関する 積層ゴム加力実験( その 1 2), 日本建築学会大会学術講演梗概集 B, pp.817-820, 2009.8

12）森隆浩, 加藤秀章, 竹内貞光, 菊地隆志, 室田伸夫 : 風荷重の動的成分が 高減衰系積層ゴムの応答特性に与える影響に関する実験的研究及びその 解析モデルの検討, 日本建築学会構造系論文集, 第 77 巻, 第 676 号, pp.823-832, 2012.6

13）森隆浩, 加藤秀章, 室田伸夫 : 変形履歴積分型の弹塑性構成則を用いた 高減衰積層ゴムの FEM 解析, 日本建築学会構造系論文集, 第 75 巻, 第 658 号, pp.2171-2178, 2010.12

14) Takahiro Mori, Hideaki Kato, Takashi Kikuchi, Nobuo Murota, Elastic-plastic Constitutive Law of Rubber for Laminated Rubber Bearings., 12th World Conference on Seismic Isolation, Energy Dissipation and Active Vibration Control of Structures, Sochi, Russia, 2011.9

15) 加藤秀章, 森隆浩, 室田伸夫, 石井建, 菊地優 : 高減衰積層ゴムの変形履 歴積分型復元力モデルに関する研究, 日本建築学会構造系論文集, 第 76 巻, 第 667 号, pp.1721-1728, 2011.9

16) C. Miehe, Discontinuous and Continuous Damage Evolution in Ogden-type Large-strain Elastic Material., Eur. J. Mech. A/Solids, 14, pp.697-720, 1995

17） MSC.MARC ユーザーズマニュアル D 編, 2003

18）室田伸夫, 菊地隆志, 西村圭司, 奥津宣幸, 鍬本賢二, 鈴木重信 : 荷重履 歴依存性を改良した新高減衰積層ゴムの開発(その $1 \sim 2$ ), 日本建築学 会大会学術講演梗概集, B- II, pp.879-882, 2007.8

19）(株)ブリヂストン：高隇衰ゴム技術資料, 2009.4

20）日本建築学会 : 鋼構造設計基準，丸善, 2002

21）手塚則雄，米山猛：設計者に必要な材料の基礎知識，日刊工業新聞社， 2003

（2012年 3 月 9 日原稿受理，2012年 7 月 2 日採用決定） 